\title{
Structural Model of the Relationships Among Mothers' Reactions to Early Adolescents' Anger, Early Adolescents' Anger Management Styles, and Internalizing Problem Behaviors
}

\author{
Na Hyeon Kim, Hee Hwa Kim \\ Department of Child Development \& Family Studies, Pusan National University, Pusan, Korea \\ 초기 청소년의 분노표현에 대한 어머니 반응, 청소년의 분노관리방식 및 \\ 내재화 문제행동 간의 구조모형 \\ 김나현, 김희화 \\ 부산대학교 아동가족학과
}

Objective: The purpose of this study was to investigate the structural model of the relationships among mothers' reactions to early adolescents' anger, early adolescents' anger management styles and internalizing problem behaviors.

Methods: The participants were 460 adolescents who were in the 1st and 2nd grade in middle schools in Pusan. Internalizing problem behaviors, mothers' reactions to early adolescents' anger, and anger management styles were measured through self-report questionnaires. Data analysis methods included Cronbach's $\alpha$, Pearson's correlation analysis, and Structural Equation Modeling. Data were analyzed using SPSS ver. 23 and Amos 23.0 programs.

Results: Mothers' anger-supportive reactions had an indirect influence on adolescents' internalizing problem behaviors mediated by adolescents' anger-coping and anger-in. Additionally, mothers' anger-rejective reactions had an indirect influence on internalizing problem behaviors mediated by adolescents' anger-out.

Conclusion: The findings from this study indicate that first, mothers should reduce adolescents' anger-out by decreasing anger-rejective reactions to prevent internalizing problem behaviors. Second, mothers should develop adolescents' anger-coping and reduce adolescents' anger-in by increasing anger-supportive reactions to reduce adolescents' internalizing problem behaviors.

Keywords: mothers' anger-supportive reactions, mothers' anger-rejective reactions, anger management styles, internalizing problem behaviors

\section{서론}

내재화 문제행동은 사회적 위축, 불안, 우울 등과 같이 개인 의 정서를 과잉통제함으로서 나타나는 자기지향적 행동을 일

Corresponding Author: Heehwa Kim, Department of Child Development \& Family Studies, Pusan National University, 2, Busandaehak-ro 63beongil, Geumjeong-gu, Busan, Korea

E-mail: hwakim@pusan.ac.kr
컫는다(Achenbach \& Rescorla, 2001). 청소년기 내재화 문제행 동은 다수의 청소년이 경험할 만큼 보편적 심리적 어려움이 며 학교생활에서의 실패, 자살충동, 성인기 문제 등을 초래한 다(H.-H. Kim, 2016). 초기 청소년의 내재화 문제가 보편적으

(C)The Korean Association of Child Studies

This is an Open Access article distributed under the terms of the Creative Commons Attribution Non-Commercial License (http:// creativecommons.org/licenses/by-nc/4.0) which permits unrestricted noncommercial use, distribution, and reproduction in any medium, provided the original work is properly cited. 
로 일어나는 데에는 청소년의 정서발달특성이 기여한다. 초 기 청소년은 자율욕구가 증가하고 자의식이 강해지는 반면 발 달적 변화에 적응하는 과정에서 정서적 갈등과 욕구불만을 많 이 경험함으로서(M. H. Kim, 2011) 분노를 빈번히 경험한다. 청소년은 생리적으로 분노와 같은 즉각적이고 강렬한 감정을 처리하는 편도체의 발달이 완성되어 감정이 풍부하고 예민해 지는데 반해, 전전두엽의 실행기능은 발달 미완성으로 판단 과 조절능력은 미숙한 상태가 된다(Somerville, Jones, \& Casey, 2010). 이러한 뇌발달 불균형으로 청소년은 다른 발달단계보 다 분노관리에 취약하다(Zeman, Klimes-Dougan, Cassano, \& Adrian, 2007). 특히 청소년의 분노를 자신으로 돌리거나 과 다하게 분노를 표출하는 분노관리실패는 다른 발달단계보다 내재화 문제행동을 더 쉽게 유발하는 요인이다(Shortt et al., 2016).

질풍노도의 시기로 불리는 청소년기는 최근 중 2 병, 중 1 병 으로 불리며 우리사회에서 이 세대는 무서운 아이들로 지각 된다. 그러나 정작 청소년은 이러한 분노관리실패현상에 대 해 '내가 왜 자꾸 화나 짜증이 나는지 내 마음 나도 몰라요. 하 지만 부모님께 이해받고 공감받고 싶어요. 나도 우울하고 힘 들어요'라고 호소한다(Christian Broadcasting System, 2016). 이 렇듯 청소년의 분노로 인한 내재화 문제행동을 예방하기 위해 서는 자녀의 분노를 다루어주는 분노사회화요인 탐색과 분노 사회화 경로 이해가 필요할 것으로 시사된다. 최근 외현화 문 제행동에 대한 분노사회화 경로 연구가 일부 수행되고 있지만 (N. H. Kim \& Kim, 2017; Shortt et al., 2010) 내재화 문제행동 에 대한 경험적 연구는 부족하다.

이제까지 문제행동의 일차적 원인으로 부모의 양육행동 이 빈번하게 연구되어왔으나(Dodge, Coie, \& Lynam, 2006) 초 기 청소년의 분노관리취약성을 고려한다면 일반적인 부모양 육은 정서를 구체적으로 반영하기 보다는 포괄적 양육이므로 문제행동의 예측요인으로서 보다 적절한 요인이 필요함이 제 기되어왔다(Denham, Basset, \& Wyatt, 2007). 그러므로 이러한 사회적 학문적 분위기를 반영한다면 청소년의 분노와 직접적 으로 상호작용하는 부모반응의 영향을 살펴보는 것이 더 유 용하다. 분노표현에 대한 부모의 반응이란 자녀의 분노를 사 회화시키는 구체적인 양육실제를 일컫는다(O’Neal \& Magai, 2005). N. H. Kim (2017)은 O'neal과 Magai (2005)의 특정정서 별 부모반응문항에 우리나라 초기 청소년을 대상으로 예비조 사를 통해 분노대처도움 반응위주로 문항을 더 추가하여 분노 지원반응과 분노거부반응으로 구분한 바 있다. 분노지원반응 은 청소년의 분노를 이해하고 적절한 위안과 공감을 제공하는
분노수용반응과 자녀가 분노를 조절하고 대처하며 문제를 해 결하도록 돕는 분노대처도움반응으로 구성된다. 분노거부반 응은 자녀의 분노표현을 방해하거나 억압하는 반응으로 분노 처벌, 무시, 축소, 과민 반응으로 구성된다.

차별적 정서이론가들에 따르면 분노와 슬픔은 그 사회화 경로가 다른데, 가령 슬픔정서는 중요타인으로부터 처벌반응 보다 위안과 지지반응을 이끌어 내고 분노정서는 처벌과 무시 반응을 이끌어 내기 쉽다(Malatesta \& Wilson, 1988; MalatestaMagai, 1991). 분노정서에 대한 부모반응이 다른 정서에 대한 반응보다 더 거부적이어서 청소년의 부적응을 유발할 것이라 는 차별적 정서이론가들의 가정은 실증적 근거에서도 드러난 다. O'neal과 Magai (2005)의 연구에서 특정정서별 어머니 반 응에 관한 신뢰도 분석결과 분노에 대한 어머니 반응이 분노 축소반응을 제외하고 모두 슬픔에 대한 어머니 반응보다 신뢰 도가 더 높게 나타났다. 이는 어머니들이 자녀의 분노표현에 대해서 더 일관성 있게 반응한다는 증거이다. 또 확인적 요인 분석결과 축소와 과민반응을 제외하고 슬픔보다 분노표현에 대한 어머니 반응의 요인부하량이 높게 나타났다. 이는 초기 청소년은 부모-자녀 갈등으로 분노를 더 잘 표출하고 부모가 다른 정서보다 분노표현에 대해 반응할 기회가 높음을 의미한 다. 또한 이들 연구에서 자녀의 슬픔표현에 대한 축소 및 과민 반응은 내재화 문제행동과 관련성이 없고 슬픔무시 및 슬픔 처벌반응은 분노무시 및 분노처벌 반응보다 내재화 문제행동 과 관련성이 낮은 것으로 나타났다. 반면 어머니의 분노거부 반응은 모두 문제행동과 유의미한 관련성을 보이므로 슬픔과 분노를 통합한 전반적 부정정서표현에 대한 반응보다 분노표 현에 대한 어머니 반응이 내재화 문제행동에 보다 명확한 설 명을 제공할 수 있다. Klimes-Dougan 등은 초기 청소년의 문제 행동을 다룬 연구에서 분노과민반응은 분노거부반응으로 슬 픔과민반응은 슬픔지지반응으로 간주됨을 지적하여(KlimesDougan et al., 2007) 유사한 과민반응이라도 분노와 슬픔에 따 라 어머니의 역할이 달라짐을 시사하였다. 이제까지 특히 국 내의 부정정서표현에 대한 어머니반응에 관한 연구들은 분노 와 슬픔을 통합한 전반적 부정적 정서표현에 대한 반응으로 측정하였고 분노표현에 초점을 두지 않았다. 부정적 정서표현 에 대한 부모반응에 관한 선행연구들의 한계점은 대표적 부정 적 정서인 분노와 슬픔에 대한 부모반응의 차이를 고려하지 않음으로써 청소년의 문제행동에 대한 설명력이 충분하지 못 함에 있다. 이러한 이유로 본 연구에서는 초기 청소년의 분노 표현에 대한 어머니 반응에 초점을 두고자 한다.

초기 청소년은 자율욕구 및 추상적 사고의 진전으로 반항 
심이 증가하여 부모와의 갈등상황에서 욕구불만을 많이 경 험하므로(Smetana, 2011) 분노를 많이 표출한다. 그런데 어머 니-청소년 갈등상황을 갈등빈도 위주로 측정한 연구들은 이 러한 청소년의 정서적 발달특성을 반영하지 못한다는 제한점 이 있다. 이러한 제한점을 반영하여 부모-청소년 갈등상황을 정서적 과정이나 정서적 반응으로 측정하려는 연구들이 최근 증가하고 있다(Hofer et al., 2013; Lundell, Grusec, McShane, \& Davidov, 2008; Moed et al., 2015). 청소년기에도 어머니는 여 전히 자녀와 정서적 유대감을 유지하고 정서적 안내자 역할을 하므로 어머니는 자녀가 표출하는 분노표현을 이해하고 공감 과 위로를 제공하면서 문제해결을 할 수 있게 도와주어야 한 다. 그러나 오히려 자녀의 연령이 높아짐에 따라 자녀가 분노 관리를 더 잘 할 것으로 기대하면서 감정지원반응은 감소하고 감정거부반응이 증가하는 것으로 보고된다(K.-H. Park, 2009; Klimes-Dougan, et al., 2007).

어머니가 청소년 자녀의 분노를 이해하고 공감하며 대처할 수 있게 도와주는 분노지원반응을 할수록 자녀는 낮은 우울증 상을 보이고(Schwartz, et al., 2012) 청소년의 분노표현을 억압 하고 방해하는 분노거부반응을 보일 경우 자녀는 자신의 분노 를 억누르고 조절하지 못해 우울과 불안을 경험한다(Sanders, Zeman, Poon, \& Miller, 2015; Schwartz et al., 2011). 즉 청소년 의 분노표현에 대한 어머니의 반응은 청소년의 내재화 문제행 동에 직접적 영향을 미친다.

이상의 연구들은 어머니의 반응과 청소년 내재화 문제행 동 간의 직접적 관련성만을 연구함으로써 분노표현에 대한 어 머니의 반응과 내재화 문제행동 간의 관계에서 청소년의 심리 내적 매개과정에 대한 설명을 제공하지 못하는 제한점이 있 다. 정서사회화 관점(Eisenberg, Cumberland, \& Spinard, 1998; Gottman, Katz, \& Hooven, 1996; Katz, Maliken, \& Stettler, 2012; Morris, Silk, Steinberg, Myers, \& Robinson, 2007)의 매개모형은 부정적 정서에 대한 부모의 반응과 청소년 적응사이의 매개 변인으로 정서조절을 가정하였고 경험적 연구들도 이 모형의 유효성을 입증하고 있다. Cunningham 등(2009)은 지역폭력에 노출된 아프리카계 미국인 소년을 대상으로 어머니의 감정지 원반응이 청소년의 정서조절을 통해 문제행동 감소로 연결되 는 과정을 확인하였다. Buckholdt 등(2014)의 연구에서 부모의 감정거부반응은 청소년의 부정적 정서대처능력을 저해하여 문제행동을 유발하는 것으로 나타났다. 학령중기 이후의 청 소년은 능동적으로 정서관리방식을 습득하므로(Morris et al., 2007) 분노표현에 대한 어머니의 반응과 내재화 문제행동 간 의 관계를 청소년의 분노관리방식이 매개한다는 예측이 가능
하다.

분노관리방식이란 분노에 대한 개인의 대응방식을 일컫는 것으로 분노를 적절히 통제하는 분노대처, 분노를 과도하게 통제하는 분노억제, 그리고 분노통제에 실패한 분노과잉표출 로 나눌 수 있다(Zeman, Shipman, \& Penza-Clyve, 2001). 청소 년의 분노관리방식은 문제행동의 심리적 근원으로 간주될 만 큼 문제행동의 직접적 요인이다. 분노에 적절히 대응하고 상 황에 맞게 표현하는 분노대처는 내재화 문제행동을 감소시켰 다(Joo, 2009; Zeman, Shipman, \& Suveg, 2002). 그러나 청소년 은 정서발달특성상 분노대처에 실패하기 쉬우므로 분노억제 나 분노과잉표출의 방식을 사용하기 쉽다. 과도하게 분노를 자신의 내면으로 돌리거나 억압하는 분노억제는 실질적인 내 면의 분노를 해소하지 못한 상태이므로 위축, 우울감과 절망 감 등 내재화 문제행동의 주된 요인으로 작용했다(H. Y. Kim, 2015). 상황에 부적절하게 분노를 과잉표출하면 타인의 수용 을 받지 못하며 비난이나 거부와 같은 부정적 평가를 받으므 로 우울, 불안과 같은 내재화 문제행동도 나타냈다(Ihm, Song, \& Kim, 2012; Joo, 2009).

청소년의 분노관리방식이 분노표현에 대한 부모반응의 영 향을 받는다는 이론적 경험적 근거가 있다. 이 경로에 대한 이 론적 근거는 Eisenberg, Cumberland와 Spinard (1998)의 정서사 회화 모델에서 찾을 수 있다. 양육자 또는 성인의 정서반응은 자녀에게 모델링 역할을 제공하고 양육자와 자녀와의 정서적 상호작용을 통해 정서에 대한 학습의 기회를 제공하는 것이 정 서사회화이다. 이들은 특히 자녀의 부정적 정서에 대한 부모반 응이 자녀의 부정적 정서를 잘 조절하도록 사회화한다고 강조 하였다. 이를 지지하는 경험적 연구들도 있다. Sanders 등(2015) 은 청소년의 분노를 대수롭지 않게 생각하거나 억압, 무시, 처 벌하는 부모의 분노거부반응은 청소년이 자신의 좌절감을 폭 발하게 하므로 분노과잉표출과는 정적인 관계를, 청소년의 분 노대처와는 부적 관계임을 보고했다. E. J. Kim (2011)의 연구 에서 부정적 정서의 수용과 친밀감을 갖게 하는 부모의 감정지 지반응은 자녀가 자신의 분노를 잘 다룰 수 있다는 자신감을 부여하므로 분노대처와 정적인 영향을, 분노과잉표출에는 부 적인 영향을 미치고, 감정축소반응은 분노억제에 정적인 영향 을 주는 것으로 나타났다. 부모의 공감적 반응과 분노억제는 부적인 관련성을 보이는 것으로 나타나서(Shin, 2013) 부모의 분노지원과 분노거부반응은 정적 관계의 분노관리방식 뿐만 아니라 부적 관계의 분노관리방식에도 영향을 미친다.

이러한 이론과 경험적 연구를 바탕으로 청소년의 분노를 공감하고 분노관리를 도와주는 어머니의 분노지원반응은 청 
소년이 분노를 잘 관리할 수 있다는 자신감을 부여하므로 분 노과잉표출 및 분노억제를 막아주고 자신과 타인의 욕구 및 감정을 고려하여 자신의 분노를 상대방에게 건설적으로 표현 하고 대처하게 하여 내재화 문제행동이 감소되는 것으로 가 정할 수 있다. 반면, 청소년의 감정을 헤아리지 못하거나 대수 롭지 않게 여겨서 청소년의 분노표현을 억압하거나 방해하 는 분노거부반응은 청소년이 타인의 입장은 고려하지 않고 좌 절감을 폭발하는 분노과잉표출을 보이거나 죄책감을 느껴서 분노억제하거나 분노대처는 어렵게 하는 등 분노를 역기능 적으로 처리하여 내재화 문제를 일으킨다고 예측할 수 있다. 즉, 분노표현에 대한 어머니의 반응은 청소년의 분노관리방식 에 매개되어 내재화 문제행동에 간접적 영향을 미칠 것으로 가정된다. 부정적 정서표현에 초점을 둔 정서사회화 관점의 매개과정 연구들(Buckholdt et al., 2014; Cunningham, Wendy, \& Garner, 2009)에 비해 차별적 정서사회화 관점에 근거하여 분노표현에 초점을 둔 매개과정 연구는 소수의 실증적 자료 (Shortt et al., 2010)를 제외하고 희소하다.

이상과 같이 청소년의 분노표현에 대한 어머니의 반응은 내재화 문제행동에 직접적인 영향도 미치지만 청소년의 분노 관리방식에 매개되어 간접적인 영향도 미친다는 인과적 구조 모형을 가정할 수 있다. 본 연구의 목적은 어머니-청소년 갈등 상황에서 청소년의 분노표현에 대한 어머니의 반응과 청소년 의 분노관리 방식 및 내재화 문제행동 간의 구조관계를 분석 하여 초기 청소년의 내재화 문제행동에 대한 분노사회화 경로 를 이해하고 청소년 및 부모상담현장에 유용한 자료를 제공하 고자 한다.

선행연구와 이론에 근거한 본 연구의 가설적 연구모형을 Figure 1에 제시하고자 한다.

연구가설은 다음과 같다. 초기 청소년의 분노표현에 대한
어머니 반응은 내재화 문제행동에 직접적인 영향도 미치지만 청소년의 분노관리방식에 매개되어 간접적인 영향도 미칠 것 이다.

\section{연구방법}

\section{연구대상}

본 연구의 대상은 중학교 1,2 학년 남녀 460 명이다. 부산시 3 개구에 위치한 3 개 중학교를 대상으로 단순집락표집에 의해 추출하였다. 표집된 3 개 학교에서 각각 4학급, 5 학급, 5 학급의 총 14 학급을 선정하였다. 중학교 1,2 학년으로 연구대상을 선 정한 근거는 이 연령층이 다른 발달단계보다 특히 분노표출이 증가하며 어머니와의 갈등이 심해지기 때문이다(Lundell et al., 2008; Smetana, 2011).

자료수집은 2016년 7월과 8월 사이에 이루어졌으며, 담임 교사가 종례 후에 내재화 문제행동과 관련변인에 대한 질문지 를 조사하였다. 총 490부를 배포해 480부를 회수하였으며 회 수된 480 부 중 응답이 누락됐거나 불성실한 응답을 제외하고 460 부를 최종분석 자료로 사용하였다.

\section{연구도구}

\section{내재화 문제행동}

청소년의 내재화 문제행동을 측정하기 위해 J. K. Park이 번 안한 척도(2001)를 사용하였다. J. K. Park (2001)의 척도는 Achenbach (1993)의 아동/청소년 행동 및 정서 문제에 관한 문 항들 가운데 외현화 및 내재화 문제행동 문항들을 번안한 것

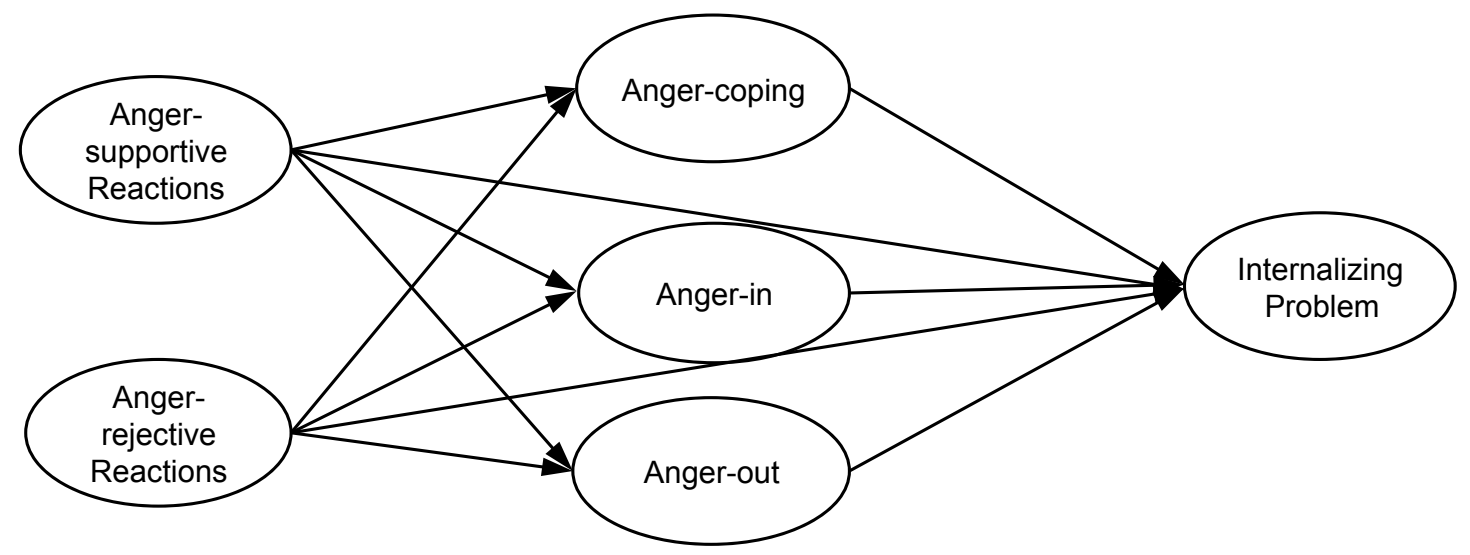

Figure 1. Hypothesized model. 
이다. 본 연구에서는 J. K. Park (2001)이 사용한 내재화 문제행 동 4점 리커트 척도를 정규분포가 되기 용이하도록 5점 리커 트 척도로 바꾸어 사용하였다. 내재화 문제행동은 불안/우울 15 문항, 위축 7 문항으로 총 22문항으로 구성된다. 각 문항의 응답범주는 거의 그렇지 않다(1점)에서 매우 그렇다(5점)의 1-5점으로 총 점수는 22점에서 110 점 사이이다. 점수가 높을 수록 내재화 문제행동 수준이 높음을 의미한다. 본 연구의 내 재화 문제행동 척도의 신뢰도 계수 Cronbach's $\alpha$ 값은 .92이다.

\section{청소년의 분노표현에 대한 어머니의 반응}

어머니-청소년 갈등상황에서 분노표현에 대한 어머니 반응을 측정하기 위해서 N. H. Kim의 척도(2017)를 사용하였다. N. H. Kim의 척도(2017)는 O'neal과 Magai (2005)의 척도 15문항 에 예비조사를 통해 추출한 7문항을 추가하여 2요인 지정하 여 탐색적 요인분석을 실시하였다. 탐색적 요인분석 결과 요 인부하량이 미미한(.23) 분노축소 1 문항을 제외하고 총 10 문 항의 분노지원반응과 11 문항의 분노거부반응으로 수정 보완 하였다. 이 척도는 어머니와의 갈등상황에서 청소년이 지각한 어머니의 반응을 측정하도록 하였다. 각 문항의 응답범주는 전혀 그렇지 않다(1점)에서 매우 그렇다(5점)까지의 5점 리커 트 척도이다. 점수가 높을수록 어머니의 분노지원 반응 및 분 노거부 반응수준이 높음을 의미한다. 분노표현에 대한 어머니 반응 척도의 Cronbach's $\alpha$ 값은 분노지원반응은 .90, 분노거부 반응은 .88 이다.

\section{분노관리방식}

초기 청소년의 분노관리방식 척도는 Zeman 등(2001)의 척도 를 본 연구자가 번안하여 사용하였다. Zeman 등(2001)이 개발 한 척도는 분노억제 4 문항, 분노과잉표출 3 문항, 분노대처 4
문항의 총 11 문항으로 구성되어 있다. 각 문항의 응답범주는 전혀 그렇지 않다(1점)에서 매우 그렇다(5점)까지로 5점 리커 트 척도이다. 점수가 높을수록 각각의 분노관리방식 수준이 높음을 의미한다. 분노관리방식 척도의 Cronbach's $\alpha$ 값은 분 노대처는 .71, 분노억제는 .74, 분노과잉표출은 .65이다.

\section{자료분석}

본 연구의 자료들은 IBM SPSS ver. 23 (IBM Co., Armonk, NY) 과 AMOS 23.0 (IBM Co., Armonk, NY) 통계 프로그램으로 분 석하였다.

첫째, 척도의 신뢰도 분석을 위해 Cronbach's $\alpha$ 계수를 산출 하였다. 연구변인들의 관련성을 알아보기 위해 Pearson의 상관 관계분석을 실시하였다.

둘째, 연구가설에서 제시한 청소년의 분노표현에 대한 어머 니반응, 청소년의 분노관리방식 및 내재화 문제행동 간의 구 조관계를 파악하기 위해 우선 확인적 요인분석을 통해 측정모 델의 타당도를 구하였다. 다음으로 구조모델의 추정치를 통해 변인들 간의 직간접 효과를 살펴보고 부트스트랩 검증방식을 사용하여 간접효과와 총효과의 통계적 유의성을 검증하였다.

\section{연구결과}

\section{연구변인들 간의 상관관계}

연구변인들 간의 상관분석을 실시한 결과가 Table 1 에 제시되 어있다. Table 1 에 의하면 내재화 문제행동과 독립변인들 간 의 상관을 크기순으로 보면, 분노억제 $(r=.35, p<.001)$, 분노 과잉표출 $(r=.35, p<.001)$, 어머니의 분노거부반응 $(r=.27, p<$ $.001)$, 어머니의 분노지원반응 $(r=-.22, p<.001)$, 분노대처 $(r=$ $-.20, p<.001)$ 순이다.

Table 1

Correlation Among Major Variables

\begin{tabular}{lccccc}
\hline & 1 & 2 & 3 & 4 & 5 \\
\hline 1. Internalizing problem & - & & & \\
2. Anger- supported & $-.22^{* * *}$ & - & & \\
3. Anger-rejected & $.27^{* * *}$ & $-.46^{* * *}$ & - & $-.21^{* * *}$ & - \\
4. Anger-coping & $-.20^{* * *}$ & $.29^{* * *}$ & .06 & $.22^{* * *}$ & - \\
5. Anger-in & $.35^{* * *}$ & $-.11^{*}$ & $.29^{* * *}$ & $-.28^{* * *}$ & .06 \\
6. Anger-out & $.35^{* * *}$ & $-.18^{* * *}$ & & - \\
\hline
\end{tabular}

${ }^{*} p<.05 .{ }^{* * *} p<.001$. 


\section{측정모델의 타당도}

확인적 요인분석으로 측정모델의 적합도, 수렴타당도 및 판별 타당도를 검토하였다. 측정모델의 적합도지수를 산출한 결과 는 아래 Table 2에 제시하였다.

Table 2

Model Fit Indices for Measurement Model

\begin{tabular}{cccccccc}
\hline$\chi^{2}$ & $d f$ & $p$ & $\chi^{2} / d$ & GFI & TLI & CFI & $\begin{array}{c}\text { RMSEA } \\
(90 \% \text { CI })\end{array}$ \\
\hline 166.85 & 76 & .00 & 2.2 & .95 & .96 & .97 & .05 \\
\hline
\end{tabular}

SEM (Structural Equation Model)의 적합도 평가는 절대적합도 지수인 Chi-Square $\left(\chi^{2}\right)$ 값, 표본크기에 영향을 받지 않는 절대 적합도 지수인 GFI, 상대적 적합도 지수인 TLI, 그리고 비교 적합도 지수인 $\mathrm{CFI}$, 모형의 간명도를 고려하는 RMSEA 등의 모든 적합도지수가 적합도 기준에 맞아야 한다(Hong, 2013).
Table 2에 따르면 측정모델의 $\chi^{2}$ 값은 166.85 ( $\left.d f=76, p<.001\right)$ 로 $p$ 가 .05보다 커야한다는 수용기준을 충족시키지 못한다. 그 러나 $\chi^{2}$ 값은 표본크기에 민감하므로 다른 적합도 지수와 함께 고려하여 평가하여야 한다(Hong, 2013). GFI는 .95, TLI는 .96, CFI는 .97로 기준값 .90이상으로 나타나서 수용되는 적합도이 다. RMSEA는 .05로 나타나서 매우 좋은 적합도를 보였다. 따 라서 본 연구의 측정모델의 적합도는 양호하다고 할 수 있다.

분노대처, 분노억제, 분노과잉표출의 분노관리방식 각각 의 변수들은 단일요인으로 관련문항들이 하나의 관측변수를 구성한다. Amos프로그램의 구동이 잘되고 식별하기 위해 단 일 요인의 문항들을 그대로 사용하지 않고 문항꾸러미를 통해 2-3개의 관측변수를 구성하였다. 이때 요인부하량 균형이 맞 도록 문항꾸러미를 구성하였다.

다음으로 잠재변인의 수렴타당도 및 판별타당도를 검증하 였다. 수렴타당도의 조건은 각 잠재변수들을 측정하기 위해 선정된 관측변수들의 요인부하량 절대값이 .50 이상이 되어야

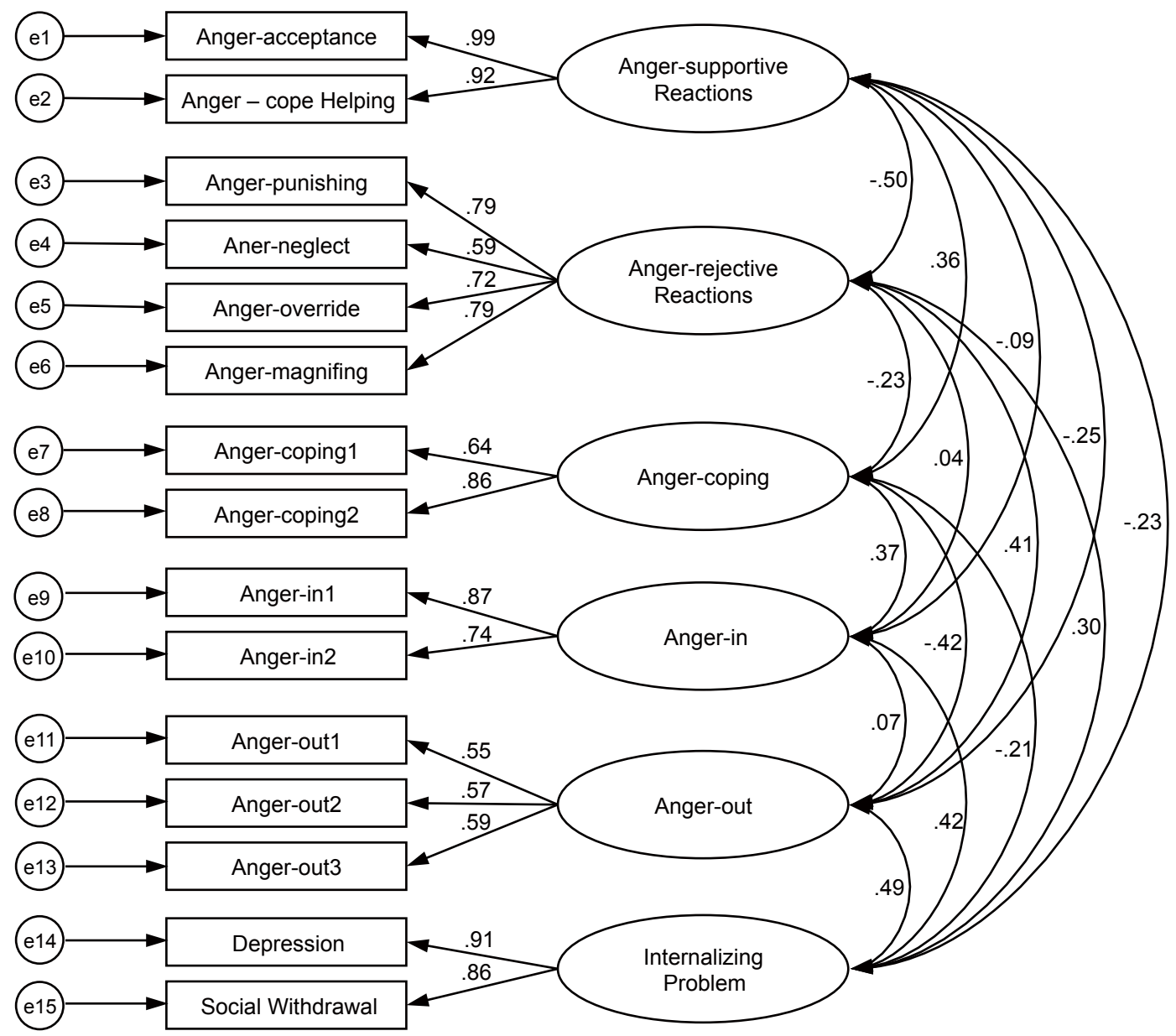

Fingre 2. Confirmatory factor analysis of the measurement model. 
Table 3

Comparison of Model Fit Indices

\begin{tabular}{lrrrrrrrr}
\hline & \multicolumn{1}{c}{$\chi^{2}$} & $d f$ & $p$ & $\chi^{2} / d f$ & NFI & TLI & CFI & $\begin{array}{c}\text { RMSEA } \\
(90 \% \text { CI })\end{array}$ \\
\hline Research model & 255.70 & 79 & .00 & 3.24 & .91 & .92 & .94 & .07 \\
Modified model & 261.00 & 84 & .00 & 3.11 & .93 & .92 & .94 & .07 \\
Difference & 5.30 & 5 & & .13 & .02 & & & \\
\hline
\end{tabular}

Table 4

Path Coefficient for Research Model

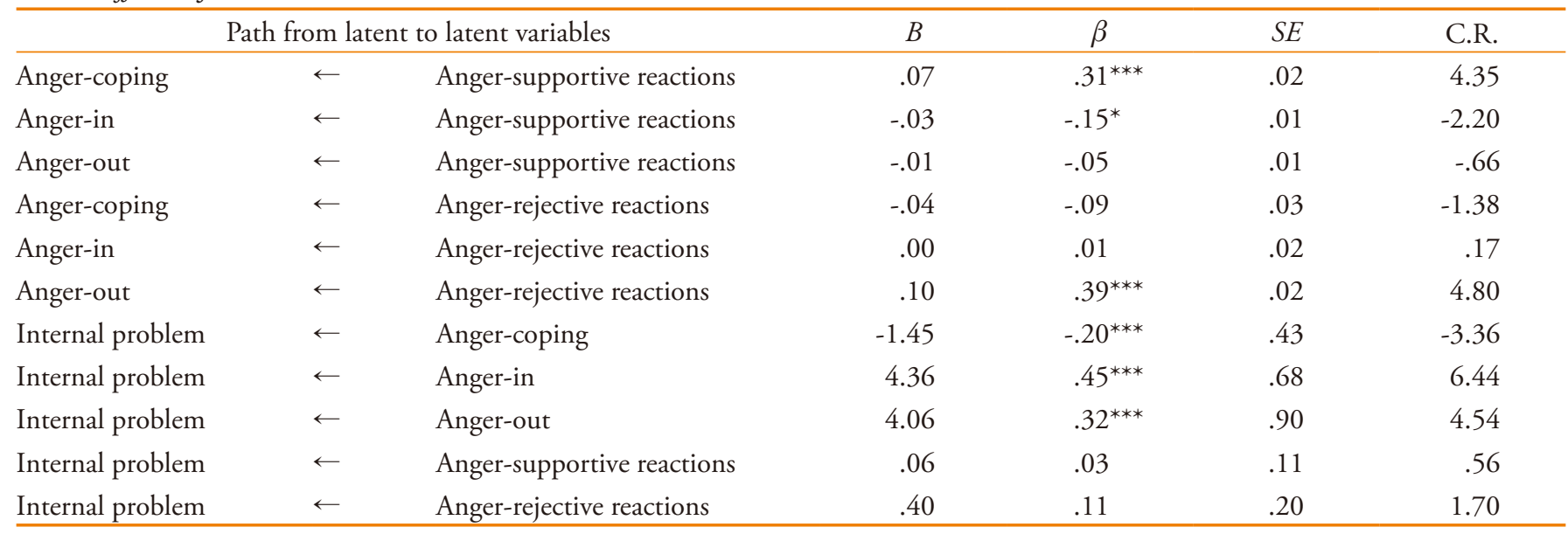

${ }^{*} p<.05$. ${ }^{* * *} p<.001$.

한다. 판별타당도 기준은 잠재변인 간의 상관계수는 .85이하 여야 한다(Bae, 2014). 확인적 요인분석을 통해 측정모델의 모 수치를 추정한 결과는 Figure 2 와 같다. 모든 잠재변수들의 관 측변수로의 표준화 회귀계수는 .55 .99으로 수렴적 타당성이 확인되었다. 또한 잠재변인 간의 상관계수가 -.50 .49 사이로 나타나 .85 이하의 기준을 충족하므로 양호한 변별성을 가지는 것으로 나타났다.

\section{구조모형 검증}

연구가설에 따라 설정한 연구모형의 적합도를 Table 3에 제 시하였다. 본 연구모형의 $\chi^{2}$ 값은 $255.70(d f=79, p<.001)$ 으 로 $p>.05$ 보다 커야 한다는 수용기준을 충족하지 못하였다. RMSEA는 .07로 나타나서 매우 좋은 적합도는 아니지만 대체 로 괜찮은 적합도 지수이다. NFI는 .91, TLI는 .92, $\mathrm{CFI}$ 는 .94로 나타나서 전체적인 적합도 지수가 양호한 것으로 나타났다. 그러나 이론적으로 가능한 모든 경로로 구성된 초기연구모형 은 유의하지 않은 경로들이 나타남에 따라 구조모델의 간명성 을 고려할 때 좋은 모델이라 할 수 없다(Hong, 2013). 따라서
초기연구모형의 유의하지 않은 경로를 제거한 모델이 보다 더 간명하여 수정모델을 설정하고 수정모델의 적합도를 Table 3 에 제시하였다.

수정모형의 $\chi^{2}$ 값은 $261.00(d f=84, p<.001)$ 로 $p>.05$ 보다 커야 한다는 수용기준을 충족하지 못하였다. RMSEA는 .07로 나타나서 매우 좋은 적합도는 아니지만 대체로 괜찮은 적합도 지수이다. NFI는 .93, TLI는 .92, CFI는 .94로 나타나서 전체적 인 적합도 지수가 양호한 것으로 나타났다. 연구모형과 수정 모형의 적합도 비교에서 수정모형의 자유도 $(d f)$ 가 연구모형 에 비해 증가하였으며 $d f$ 차이가 5 (84-79)일 때 $\chi^{2}$ 차이는 5.30 로서 $p=.05$ 의 유의수준에서 유의한 차이가 없다. $d f$ 가 5 개 변 화했을 때 $\chi^{2}$ 차이가 11.07 이상이면 $p=.05$ 의 유의수준에서 유 의한 차이가 있다(Bae, 2014). $\chi^{2} / d f$ 값과 NFI값에서는 수정모 형이 초기 연구모형보다 더 기준치에 적합하다. 즉, 수정모형 은 연구모형보다 더 간명하면서도 적합도 차이가 없는 양호한 모형이라고 할 수 있으므로 최종모형으로 채택하였다.

수정모형의 적합도가 양호하게 부합되는 것으로 나타남에 따라 초기연구모형에서 유의하지 않은 경로는 제거하고 유의 한 경로계수로 수정모형을 만들기 위해 경로계수의 유의성을 
Table 4에 제시하였다.

Table 4에 제시한 유의미한 개별경로의 계수를 살펴보면, 분노억제 $(\beta=.45, p<.001$ 는 내재화 문제행동에 유의한 정적 영향을 미쳤다. 분노과잉표출 $(\beta=.32, p<.001)$ 은 내재화 문 제행동에 유의한 정적 영향을 미쳤다. 분노대처 $\beta=-.20, p<$ .001)는 내재화 문제행동에 유의한 부적영향을 미쳤다. 어머 니의 분노지원반응 $(\beta=.31, p<.001)$ 은 분노대처에 유의한 정 적 영향을 미쳤다. 어머니의 분노지원반응 $(\beta=-.15, p<.05)$ 은 분노억제에 유의한 부적 영향을 미쳤다. 어머니의 분노거부반 응 $(\beta=.39, p<.001)$ 은 분노과잉표출에 유의한 정적 영향을 미 쳤다. 이는 어머니의 분노지원반응이 높을수록 청소년의 분노 대처가 높아졌으며, 어머니의 분노지원반응이 높을수록 청소
년의 분노억제가 낮아졌으며, 어머니의 분노거부반응이 높을 수록 분노과잉표출이 높아졌으며, 분노억제가 높아질수록 내 재화 문제행동은 높아졌으며, 분노대처가 높아질수록 내재화 문제행동은 낮아졌으며, 분노과잉표출이 높아질수록 내재화 문제행동은 높아졌다.

초기연구모형의 유의하지 않은 경로를 제거하고 수정모형 인 최종모형의 직간접 효과를 Table 5에 제시하고 Figure 3에 도식화한 결과를 나타내었다.

Table 5, Figure 3에서 나타나는 바와 같이 청소년의 분노억 제 $(\beta=.46, p<.001)$, 분노과잉표출 $(\beta=.39, p<.001)$, 분노대 처 $(\beta=-.18, p<.001)$ 는 청소년의 내재화 문제행동에 직접적인 영향을 미쳤다. 어머니의 분노지원반응은 청소년의 분노대처

Table 5

Direct, Indirect, and Total Effects in the Structural Equation Model

\begin{tabular}{|c|c|c|c|c|c|}
\hline & & & Direct effect & Indirect effect & Total effect \\
\hline Anger-coping & $\leftarrow$ & Anger-supportive reactions & $.35^{* * *}$ & .00 & $.35^{* *}$ \\
\hline Anger-in & $\leftarrow$ & Anger-supportive reactions & $-.15^{* *}$ & .00 & $-.15^{*}$ \\
\hline Internal problem & $\leftarrow$ & Anger-coping & $-.18^{* * *}$ & .00 & $-.18^{*}$ \\
\hline Internal problem & $\leftarrow$ & Anger-in & $.46^{* * *}$ & .00 & $.46^{*}$ \\
\hline Internal problem & $\leftarrow$ & Anger-supportive reactions & .00 & $-.13^{*}$ & $-.13^{*}$ \\
\hline Internal problem & $\leftarrow$ & Anger-rejective reactions & .00 & $.17^{* *}$ & $.17^{* *}$ \\
\hline
\end{tabular}

${ }^{*} p<.05 .{ }^{* *} p<.01 .{ }^{* * *} p<.001$.

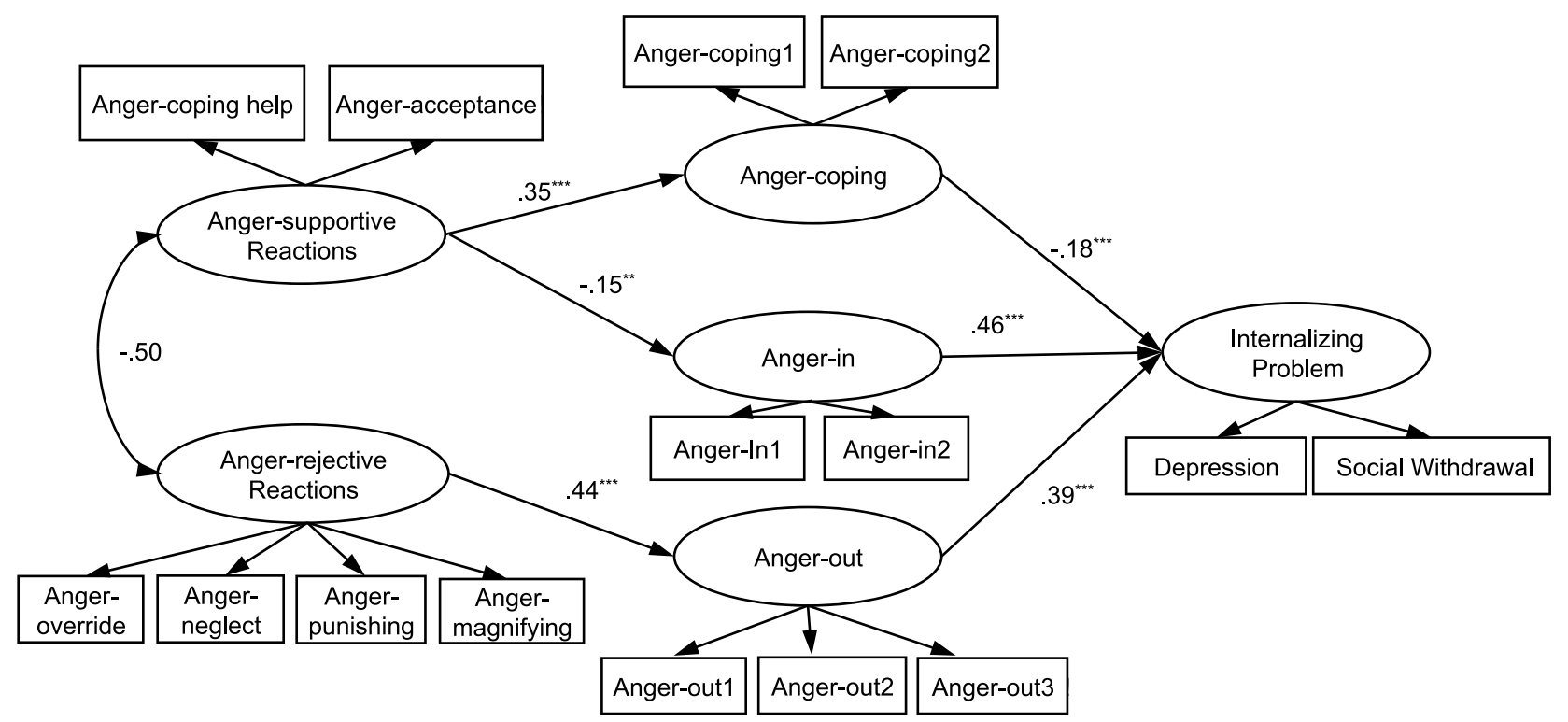

Figure 3. The final model: Structural model of relationships among mother's reactions to early adolescents' anger, early adolescents' anger management styles, and internalizing problem behaviors.

${ }^{* *} p<.01 .{ }^{* * *} p<.001$. 
$(\beta=.35, p<.001)$ 와 분노억제 $(\beta=-.15, p<.01)$ 를 통해 내재화 문제행동에 간접적인 영향 $(\beta=-.13, p<.05)$ 을 미쳤다. 어머니 의 분노거부반응은 내재화 문제행동에 분노과잉표출 $(\beta=.44$, $p<.001)$ 을 통해 간접적인 영향 $(\beta=.17, p<.10)$ 을 미쳤다. 청 소년의 내재화 문제행동에 대한 관련변인들의 총 효과를 크기 순으로 살펴보면, 분노억제 $(\beta=.46, p<.05)$, 분노과잉표출 $(\beta=$ $.39, p<.01)$, 분노대처 $(\beta=.-18, p<.05)$, 어머니의 분노거부반 응 $(\beta=.17, p<.01)$, 어머니의 분노지원반응 $(\beta=-.13, p<.05)$ 순이다.

어머니의 분노지원반응과 분노거부반응의 내재화 문제행 동에 대한 간접효과의 통계적 유의성을 부트스트랩핑 200번 반복 시행으로 검증한 결과, .015 (분노지원반응)와 .004 (분노 거부반응)로 유의한 것으로 나타났다.

\section{논의 및 결론}

본 연구의 목적은 어머니-청소년 갈등상황에서 분노표현에 대한 어머니 반응과 초기 청소년의 분노관리방식 및 내재화 문제행동 간의 구조관계를 분석하여 청소년의 내재화 문제행 동에 대한 분노사회화 경로를 이해하고 청소년 및 부모상담현 장에 기초자료를 제공하는 것이었다.

본 연구의 목적을 달성하기 위해 초기 청소년인 중학교 1,2 학년 460명을 대상으로 어머니-청소년 갈등상황에서 분노표 현에 대한 어머니 반응과 청소년의 분노관리방식 및 내재화 문제행동을 청소년 보고용으로 측정하였다. 내재화 문제행동 에 대한 분노표현에 대한 어머니 반응과 청소년의 분노관리방 식의 직접효과 및 분노표현에 대한 어머니 반응이 분노관리방 식에 매개된 간접효과를 분석하여 관련변인 간의 구조관계를 검증하였다.

본 연구결과를 다음과 같이 요약하고자 한다.

청소년의 내재화 문제행동에 어머니의 분노지원반응은 분 노대처와 분노억제에 매개되어 내재화 문제행동에 간접적인 영향만 미쳤다. 어머니의 분노거부반응은 분노과잉표출에 매 개되어 간접적인 영향만 미쳤다. 청소년의 내재화 문제행동에 대한 연구변인들의 총 효과는 초기 청소년의 분노억제, 분노 과잉표출, 분노대처, 어머니의 분노거부반응, 어머니의 분노 지원반응 순이다.

본 연구의 주요결과에 대한 논의점은 다음과 같다.

첫째, 본 연구는 Eisenberg 등(1998), Gottman 등(1996), Katz 등(2012) 및 Morris등(2007)의 정서사회화 모델에 경험적 근거
를 제시하였다는 점에서 이론적 의의를 찾을 수 있다. 이들은 정서사회화 모델에서 자녀의 정서에 대한 부모의 반응이 청소 년의 정서조절 유능성에 매개되어 적응에 영향을 미친다고 제 시하였다. 본 연구의 최종모형에서 자녀의 분노표현에 대한 어머니 반응이 청소년의 분노관리방식에 매개되어 내재화 문 제행동에 영향을 미치는 것으로 나타난 결과는 이들의 관점을 지지했다. 본 연구는 기존의 선행연구들, 즉 지역폭력에 노출 된 9-13세 아프리카계 미국 남아를 대상으로 부모의 상위정서 철학이 청소년의 정서조절에 매개되어 문제행동에 영향을 미 침을 보고한 Cunningham 등(2009)의 연구 및 어머니의 감정 거부반응이 청소년의 정서조절에 매개되어 내재화 문제행동 에 영향을 미친다는 Buckholtdt 등(2014)의 연구와 맥락을 같 이하는 결과이다. 특히 선행연구들이 청소년의 부정적 정서 전 반에 대한 부모반응을 다룬데 비해 본 연구에서는 부정적 정 서 중에서도 내재화 문제행동과 관련성이 높고 정서발달특성 상 빈번히 표출하는 청소년의 분노에 초점을 둠으로써 내재화 문제에 대한 분노사회화 경로를 제시했다는 의의가 있다. 차 별적 정서이론가들은 슬픔보다 분노에 대한 부모의 거부반응 이 청소년 내재화 문제행동과 더 관련됨을 제시했는데(KlimesDougan, et al, 2007; O’Neal \& Magai, 2005) 본 연구의 모형은 Gottman (1996)과 Eisenberg 등(1998)의 정서사회화 모델에 서 나아가 차별적 정서사회화를 주장한 학자들(Malatesta \& Wilson, 1988; Malatesta-Magai, 1991)의 관점을 반영한데서 주 목할 만한 이론적 의의가 있다고 볼 수 있다.

본 연구의 구조모형은 분노표현에 대한 부모반응과 초기 청 소년의 내재화 문제행동 간의 직접적 관계를 검토한 선행연구 들(Sanders et al., 2015; Schwartz et al., 2011; Schwartz, et al., 2012) 에서 나아가 청소년의 능동적인 분노관리방식의 매개변인을 포함시킨 점에서 청소년의 심리내적 기제를 밝혔다고 볼 수 있 다. 정서사회화 연구자들은 자녀의 감정에 대한 부모반응과 자 녀의 적응사이를 매개하는 자녀의 심리내적 기제가 몇 가지 있 음을 주장했다. Eisenberg 등(1999)은 부모의 감정지원반응은 자녀의 공감능력을 발달시키며, 정서적 각성을 줄이고 스트레 스 상황에서 대처하는 능력을 높인다고 설명했다. Gottman 등 (Gottman et al., 1996; Gottman et al., 1997)은 부모의 감정거부 반응은 자녀의 정서억제를 유발하거나 정서과잉표출하게 하 여 문제행동을 유발한다고 설명했다. 그러나 다수의 경험적 연 구들은(Buckholdt et al., 2014; Cunningham et al., 2009; Shortt et al., 2010; Yap, Schwartz, Byrne, Simmons, \& Allen, 2010) 청소년 의 심리내적 매개과정을 단일하게 설정하였다. 반면 본 연구는 분노대처, 분노억제, 분노과잉표출 각각을 매개변수로 설정한 
다중매개방식으로 분노사회화 경로를 설명하였다.

청소년의 분노관리방식 발달을 위한 분노사회화 변인으로 일반적인 양육위주로 설명한 선행연구(E.-J. Kim, 2001; Jeong, 2007; S.-A. Park, 2010)와 달리 분노표현에 대한 구체적인 반 응으로 제시하여 일반적인 양육보다는 자녀의 정서와 상호작 용하는 정서관련양육이 더 강력하고 유용한 예측요인이 될 수 있다는 주장(Denham et al., 2007)을 반영하였다. 또한 분노지 원반응으로 분노수용반응 외에도 분노대처도움반응을 포함 시켜서 동양문화권의 양육특성인 분노조절에 대한 한계설정 을 반영하였다는 점이다. 이는 기존척도의 한계점으로 부모가 감정을 무조건 수용하기 보다는 한계설정을 제공하는 태도가 필요함을 지적한 학자(Tao, Zhou, \& Wang, 2010)의 관점을 반 영한 측정이라고 할 수 있다.

둘째, 본 연구의 최종모형에서 분노표현에 대한 어머니 반 응이 내재화 문제에 미치는 직접효과는 나타나지 않아서 본 연구가설이 부분적으로 지지되었다. 이는 자녀의 정서에 대한 어머니 반응이 자녀의 정서조절을 매개해 적응에 영향을 미친 다는 정서사회화 관점을 지지하는 선행연구(Buckholdt et al., 2014; Cunningham et al., 2009)와 같은 결과이다.

본 연구의 구조관계를 상세히 살펴보면, 먼저 청소년의 분 노관리방식인 분노대처, 분노억제, 분노과잉표출이 내재화 문 제행동에 직접적인 영향을 미치는 것으로 나타난 결과는 청소 년의 분노관리방식이 문제행동의 심리적 기저변인으로 직접 요인임을 강조한 연구들(Anderson \& Bushman, 2002; Cautin, Overholse, \& Goetz, 2001; Ihm et al., 2012; Yoon, 2013; Zeman et al., 2002) 및 정서관리가 청소년의 정서발달과업임을 제시 한 연구(Cicchetti, Ganiban, \& Barret, 1991; Moriss et al, 2007) 들을 반복입증하고 있다. 즉 청소년이 어떤 분노관리방식을 주로 사용하는가가 내재화 문제행동의 유발 또는 감소와 직접 적 관련이 있는데 이는 부모의 분노반응이 어떠한가에 영향 을 받는다. 청소년이 분노억제 및 분노과잉표출을 할수록 내 재화 문제행동이 증가하며 분노대처를 할수록 내재화 문제행 동이 감소되는 것으로 나타났다. 이들 분노관리방식들의 상대 적 영향력에서 분노억제가 내재화 문제행동에 가장 큰 영향을 미친 연구결과는 관련 선행연구(Joo, 2005; Zeman et al., 2002) 와 일치한다고 볼 수 있다. Plutchik (1993)은 청소년의 정서과 잉통제가 내재화 문제행동과 밀접하게 관련된다고 밝혔는데 본 연구에서는 그가 제시한 전반적 정서과잉통제 중 특히 분 노억제가 내재화 문제행동을 설명하는 중요한 변수임을 제시 하였다. 어머니가 분노지원반응을 덜 할수록 청소년의 분노 억제가 높아진다는 본 연구 결과를 부분적으로 지지하는 연구
로 Shin (2013)의 연구를 들 수 있다. 아동을 대상으로 한 Shin (2013)의 연구에서 부모의 공감반응이 아동의 분노억제와 부 적으로 관련되었다. 즉 부모가 자녀의 감정을 이해하고 수용하 는 공감반응을 보이면 아동의 분노억제가 낮아지는 것으로 나 타났다. 이것은 분노를 억제하는 사람들은 사회적 지지가 낮고 (Palfai \& Hart, 1997) 정서를 표현했을 때 상대가 무관심하거나 지지를 안 해주면 정서표현에 갈등을 느끼거나 부정적 정서표 현신념을 가져서(Noh \& Jeong, 2010) 정서억제를 한다는(Choi, Min, \& Lee, 2008) 선행연구의 주장들과 같은 맥락에서 해석할 수 있다. 그런데 어머니의 분노지원반응이 분노억제에 미치는 영향이 다른 관계보다 다소 낮게 나타난 점은 분노억제에 미치 는 다른 사회화 변인을 고려할 필요가 있으며 청소년이 분노억 제하기 때문에 어머니의 분노지원반응이 낮을 수 있음도 고려 해야 함을 시사한다. 그러므로 후속연구를 통해 이러한 점들이 검토되어야 할 것이다.

분노억제 다음으로 청소년의 분노과잉표출이 내재화 문 제행동에 영향을 미치는 것으로 나타난 본 연구결과는 Yoon (2013) 및 Zeman 등(2002)의 연구결과와 일치한다. Zeman 등 (2002)은 분노를 적절히 대처하지 못하고 외부로 표출하는 분 노과잉표출이 일반적으로 초기 청소년의 외현화 문제행동과 관련된다고 간주되지만 내재화 문제행동과도 동시에 관련된 다는 연구결과를 제시하였다. 본 연구에서 청소년의 분노과잉 표출은 어머니가 청소년의 분노표현에 대해 축소, 무시, 처벌, 과민의 분노거부반응을 할 때 발달했다. 이는 부모의 분노거 부반응이 초기 청소년의 분노과잉표출과 관련된다는 Sanders 등(2015)의 연구결과를 지지한다.

마지막으로 내재화 문제행동를 감소시키는 분노대처는 분 노관리방식 중 가장 낮은 효과를 보였다. 청소년의 문제행동 감소의 관건인 청소년의 분노대처 능력을 발달시키기 위해서 는 청소년의 분노를 이해하고 공감하며 분노를 유발한 문제를 해결하도록 돕거나 화를 풀어주는 등 기분이 좋아지는 방법을 제안하거나 상황을 객관적으로 보도록 돕는 적극적인 분노지 원반응을 하는 것이 필요함을 시사한다. 이는 어머니의 감정 지지반응이 분노대처에 영향을 미친 E. J. Kim (2011)의 연구 와 일치한다고 볼 수 있다.

셋째, 본 연구의 최종모형은 어머니의 분노지원반응이 청 소년의 분노대처능력을 향상시키고 분노억제는 감소시켜서 내재화 문제행동을 감소시킨 경로와 어머니의 분노거부반응 은 청소년의 분노과잉표출 증가를 초래하여 내재화 문제행동 을 유발하는 경로를 각각 보여주고 있다. 즉 내재화 문제행동 감소경로와 문제행동 유발경로로 다르게 구분되어 나타나고 
어머니의 분노지원반응과 분노거부반응은 각각 다른 사회화 경로를 보여준다. 그런데 어머니의 분노지원반응이 분노억제 로 가는 경로와 분노대처가 내재화 문제행동으로 가는 경로의 영향이 다른 경로보다 낮게 나타났다. 즉 문제행동 유발경로 가 감소경로보다 내재화 문제에 대한 영향력이 더 큰 것으로 나타나서 유발경로에 우선적으로 주목할 필요가 있다.

넷째, 본 연구결과를 통한 실천적 함의를 제시하면 다음과 같다. 청소년의 내재화 문제행동을 예방하고 감소시키기 위해 서는 분노억제나 분노과잉표출이 심한 청소년에게 분노에 대 해 정확한 인식을 하게하고 보다 건설적이고 긍정적인 방법으 로 분노를 표현하고 대처하도록 분노대처방식을 발달시켜야 한다. 청소년의 내재화 문제를 상담할 경우나 내재화 문제 예 방 프로그램을 개발할 경우에 청소년의 분노대처를 도모하는 활동이나 개입전략을 마련함은 청소년의 내재화 문제행동을 완화할 것으로 시사된다. 본 연구에서 내재화 문제를 유발하 는 분노과잉표출은 어머니가 분노거부반응을 할 때 발달하므 로 청소년과의 갈등상황에서 분노거부반응이 심한 어머니는 분노무시, 축소, 과민, 처벌반응 등을 삼가는 것이 중요한 관건 임을 시사한다. 다음으로 내재화 문제를 감소시키는 분노대 처는 어머니가 청소년과의 갈등상황에서 분노표현에 대해 지 원반응을 보일 때 발달하므로 자녀의 분노가 표현되어야 함을 인식하고 표현된 자녀의 분노를 이해하고 공감해주고 대처할 수 있도록 도와주어야 한다는 태도가 도움이 될 수 있음을 시 사한다. 부모상담 현장에서나 부모교육프로그램 개발시 본 연 구결과를 활용하여 반영한다면 어머니-청소년 갈등상황에서 청소년이 표출하는 분노에 대한 부모역할을 지도하고 청소년 의 분노관리를 도모할 수 있다.

다섯째, 최근 갈등연구 학자들은 갈등의 정서적 강도가 증 가하는 청소년기 정서발달특성을 반영하려면 갈등의 정서 적 과정이나 정서적 반응으로 접근하여야 함을 제안하였다

(Smetana, Campione-Barr, \& Metzger, 2006; Steinberg \& Silk, 2002). 본 연구는 이러한 의견을 반영하여 대부분의 어머니-청 소년 갈등연구가 갈등빈도를 측정한 것과는 달리 어머니-청 소년 갈등상황에서 청소년 분노표현에 대한 어머니의 반응을 측정하여 갈등의 정서적 과정이나 정서적 반응으로 접근하여 차별화한 의의가 있다. 본 연구는 어머니-청소년 갈등상황에 서 자녀의 분노표현에 대한 어머니의 반응과 청소년의 분노관 리방식으로 측정하였다는 점에서 어머니와 청소년의 정서와 언어적 반응으로 갈등반응을 측정한 Hofer 등(2013)의 연구, 갈등의 강도를 분노수준으로 측정한 Lundell 등(2008)의 연구, 갈등의 강도를 부정적 정서의 교류로 측정한 Moed 등(2015)
의 연구와 유사한 접근을 시도했다고 할 수 있다. 또한 갈등상 황에서 어머니의 반응과 청소년의 분노관리방식이 내재화 문 제행동에 영향을 미친 본 연구결과는 어머니의 낮은 긍정적 반응이 청소년의 내재화 문제행동과 관련되는 것으로 나타난 Hofer 등(2013)의 연구결과를 부분적으로 지지한다.

본 연구의 의의를 정리하면 다음과 같다.

첫째, 본 연구의 구조모형은 차별적 정서사회화 관점을 반 영하여 초기 청소년의 내재화 문제에 대한 분노사회화 모델의 경험적 근거를 제시하였다. 슬픔과 분노를 통합한 부정적 정 서에 대한 어머니반응으로 접근하지 않고 문제행동과 관련이 보다 높은 분노표현에 대한 어머니 반응으로 접근하여 내재화 문제행동에 보다 명확한 설명력을 제공하였다.

둘째, 어머니의 분노지원반응은 분노대처와 분노억제에 매 개되어 내재화 문제에 영향을 미치는 문제감소 경로와 어머니 의 분노거부반응은 분노과잉표출에 매개되어 내재화 문제에 영향을 미치는 문제유발 경로로 구분되어 다른 사회화 경로를 보여준다. 내재화 문제 유발경로가 감소경로보다 영향력이 보 다 크므로 내재화 문제 유발경로에 우선적으로 초점을 두어야 한다. 이러한 본 연구결과를 활용하여 청소년의 내재화 문제 행동 예방과 분노대처방식 향상전략에 개입할 수 있는 부모의 역할을 각기 다른 분노사회화 경로별로 상담하거나 안내할 수 있다.

셋째, 초기 청소년의 정서발달특성 중 하나인 어머니-청소 년 갈등상황에서 분노와 같은 정서적 강도가 증가한다는 점을 반영하여 갈등빈도측정 위주인 다수연구와 달리 본 연구는 어 머니-청소년 갈등상황에서 청소년 분노표현에 대한 어머니의 반응으로 측정함으로써 어머니-청소년의 갈등상황의 정서적 과정이나 정서적 반응을 반영하였다는 의의가 있다.

본 연구의 결과를 기초로 다음과 같은 결론을 내리고자 한다. 어머니의 분노지원반응은 청소년의 분노대처를 발달시키 고 분노억제는 감소시켜 서 내재화 문제행동을 감소시킨다. 어머니의 분노거부반응은 분노과잉표출을 발달시켜서 청소 년의 내재화 문제행동을 유발한다. 내재화 문제 유발경로가 내재화 문제 감소경로보다 효과가 더 크다. 따라서 청소년의 내재화 문제행동을 예방하기 위해서 우선 어머니는 청소년과 의 갈등상황에서 분노거부반응을 삼가 하여 청소년의 분노과 잉표출을 막아주어서 내재화 문제가 유발되지 않도록 해야 한 다. 다음으로 어머니는 청소년과의 갈등상황에서 분노지원반 응을 하여 청소년이 분노억제를 낮추고 건설적인 방법으로 분 노를 표현하고 대처하도록 도와주어서 내재화 문제를 감소시 켜야 함을 함의한다. 
본 연구의 한계점 및 후속 연구를 위한 제언은 다음과 같다. 첫째, 본 연구변인들 간의 구조관계는 종단적 자료에 의한 인과관계가 아니므로 본 연구변인들 간의 구조관계에 대한 타 당도를 높이려면 후속 연구에서 종단연구를 실시하여 인과관 계를 명확히 입증할 필요가 있다.

둘째, 본 연구에서는 부모변인으로 분노표현에 대한 어머 니의 반응만 측정하여 청소년 변인과의 관계를 살펴보았다. 최근에는 아버지의 정서적 역할도 증가하고 있으므로 초기 청 소년과의 갈등상황에서 아버지 반응이 청소년 발달과 적응에 미치는 영향력을 함께 파악함은 부모변인의 설명력을 높일 수 있다. 따라서 후속연구에서 분노표현에 대한 아버지 반응을 포함시킬 필요가 있다.

셋째, 본 연구에서는 청소년의 분노표현에 대한 어머니의 반응을 자유반응조사와 질문지 조사로 문항을 수집하였으므 로 청소년이 지각하는 어머니 반응이라는 주관적 요소를 배제 하지 못하는 한계점이 있다 추후 연구에서는 어머니를 대상으 로 인터뷰나 질적 접근을 통해 문항을 수집하면 객관성을 높 이고 연구의 타당도를 더 높일 수 있을 것이다.

\section{Notes}

This article is a part of the first author's doctoral dissertation submitted in 2017, and was presented as a verbal announcement at the 2017 Annual Fall Conference of the Korean Association of Child Studies.

\section{Conflict of Interest}

No potential conflict of interest relevant to this article was reported.

\section{References}

\section{In English}

Achenbach, T. M. (1993). New Developments in Empirically Based Assessment and Taxonomy of Child/Adolescent Behavioral and Emotional Problems. Paper presented at the Annual Meeting of the American Psychological Association, Toronto, Canada.

Achenbach, T. M., \& Rescorla, L. A. (2001). Manual for the ASEBA school-age forms \& profiles. Burlington, NJ: Research Center for Children, Youth, \& Families.

Anderson, C. A., \& Bushman, B. J. (2002). Human aggression. Annual Review of Psychology. 53, 27-51. doi:10.1146/ annurev.psych.53.100901.135231

Buckholdt, K. E., Parra, G. R., \& Jobe-Shields, L. (2014). Intergenerational transmission of emotion dysregulation through parental invalidation of emotions: Implications for adolescent internalizing and externalizing behaviors. Journal of Child and Family Studies, 23(2), 324-332. doi:10.1007/ s10826-013-9768-4

Cautin, R. L, Overholse, J. C., \& Goetz, P. (2001). Assessment of mode of anger expression in adolescent psychiatric inpatients. Adolescence, 36(141), 163-170.

Cicchetti, D., Ganiban, J. A. \& Barrett, D. (1991). Contributions from the study of high risk populations to understanding the development of emotion regulation. in J. Garber \& K. A. Dodge (Eds.), The development of emotion regulation and dysregulaion (pp.15-49). New York: Cambridge University Press.

Cunningham, J. N., Wendy, K., \& Garner, P. W. (2009). Emotion socialization, child emotion understanding and regulation, and adjustment in urban african american families: Differential associations across child gender. Development and Psychopathology, 21(1), 261-283. doi:10.1017/ S0954579409000157

Denham, S. A., Basset, H. H., \& Wyatt, T. (2007). The socialization of emotional competence. In J. E. Grusec \& P. D. Hastings (Eds.), Handbook of socialization: Theory and research(pp. 614-637). New York: Guilford Press.

Dodge, K. A., Coie, J. D., \& Lynam, D. (2006). Aggression and antisocial behavior in youth. In W. Damon, R. M. Lerner(Series Ed.), and N. Eisenberg(Vol. Ed.), Handbook of Child Psychology. Vol. 3. Social, emotional, and personality development(6th ed., pp. 719-788). New York: Wiley.

Eisenberg, N., Cumberland, A., \& Spinard, T. L. (1998). Parental socialization of emotion. Psychological Inquiry, 9(4), 241273. doi:10.1207/s15327965pli0904_1

Gottman, J. M., Katz, L. F., \& Hooven, C. (1996). Parental metaemotion philosophy and the emotional life of families: Theoretical models and preliminary data. Journal of Family Psychology, 10(3), 243-268.

Gottman, J. M., Katz, L. F., \& Hooven, C. (1997). Meta-emotion: How families communicate emotionally. Hillsdale, MI: Lawrence Erlbaum Associates.

Hofer C, Eisenberg N, Spinrad T. L., Morris A. S., Gershoff E., Valiente C., Kupfer A., Eggum N. D. (2013). Motheradolescent conflict: Stability, change, and relations with externalizing and internalizing behavior problems. Social Development. 22(2), 259-279. doi:10.1111/sode.12012

Katz L. F, Maliken A. C, Stettler N. M. (2012). Parental meta- 
emotion philosophy: A review of research and theoretical framework. Child Development Perspectives. 6(4), 417-422.

Klimes-Dougan B., Brand, A. E., Zahn-Waxler, C., Usher, B., Hastings, P. D., Kendziora, K., \& Garside, R. B. (2007). Parental emotion socialization in adolescence: Differences in sex, age and problem status. Social Development, 16(2), 326-342. doi:10.1111/j.1467-9507.2007.00387.x

Lundell, L. J., Grusec, J. E. , McShane, K. E. , Davidov, M. (2008) Mother-adolescent conflict: Adolescent goals, maternal perspective-taking, and conflict intensity. Journal of Research on Adolescence, 18(3), 555-571. doi:10.1111/j.15327795.2008.00571.x

Malatesta-Magai, C. (1991). Emotion socialization: Its role in personality and developmental psychopathology. In D. Cicchetti \& S. L. Toth (Eds.), Rochester symposium on developmental psychopathology: Vol. 3. Internalizing and externalizing expressions of dysfunction(pp. 203-224). Hillsdale, MI: Erlbaum.

Malatesta, C. Z., \& Wilson, A. (1988). Emotion cognition interaction in personality development: A discrete emotions, functionalist analysis. Bristish Journal of Social Psychology, 27, 91-112. doi:10.1111/j.2044-8309.1988.tb00807.x

Moed, A., Gershoff, E. T., Eisenberg, N., Hofer, C., Losoya, S., Spinard, T. L., Liew, J. (2015). Parent-adolescent conflict as sequences of reciprocal negative emotion: Links with conflict resolution and adolescents' behavior problems. Journal of Youth and Adolescence. 44(8), 1607-1622. doi:10.1007/s10964-014-0209-5

Morris, A. S., Silk, J. S., Steinberg, L., Myers, S. S., \& Robinson, L. R. (2007). The role of the family context in the development of emotion regulation. Social Development, 16(2), 361-388. doi:10.1111/j.1467-9507.2007.00389.x

O’Neal, C. R., \& Magai, C. (2005). Do parents respond in different ways when children feel different emotions? The emotional context of parenting. Development and Psychopathology, 17(2), 467-487. doi:10.1017/ S0954579405050224

Palfai, T. P. \& Hart, K. E. (1997). Anger coping styles and perceived social support. The Journal of Social Psychology, 137(4), 405-411. doi:10.1080/00224549709595455

Plutchik, R. (1993). Emotions and their vicissitudes: Emotions and psychopathology. In M. Lewis \& J. M. Haviland (Eds.), Handbook of emotions(pp. 53-66). New York: Guilford Press.

Sanders W, Zeman J, Poon J, \& Miller R. (2015). Child regulation of negative emotions and depressive symptoms: The moderating role of parental emotion socialization. Journal of Child \& Family Studies. 24(2), 402-415. doi:10.1007/ s10826-013-9850-y

Schwartz, O. S., Dudgeon, P., Sheeber, L. B., Yap, M. B. H.,
Simmons, J. G., \& Allen, N. B. (2012). Parental behaviors during family interactions predict changes in depression and anxiety symptoms during adolescence. Journal of Abnormal Child Psychology, 40(1), 59-71. doi:10.1007/ s10802-011-9542-2

Schwartz, O. S., Dudgeon, P., Sheeber, L. B., Yap, M. B. H., Simmons, J. C., \& Allen, N. B. (2011). Observed maternal responses to adolescent behavior predict th e onset of major depression. Behaviour Research and Therapy, 49(5), 331338. doi:10.1016/j.brat.2011.02.008

Shortt, J. W., Katz, L. F., Allen, N. B., Leve, C., Davis, B., Sheeber, L. B. (2016) Emotion socialization in the context of risk and psychopathology: Mother and father socialization of anger and sadness in adolescents with depressive disorder. Social Development, 25(1), 27-46. doi:10.1111/sode.12138

Shortt, J. W., Stoolmiller, M., Smith-Shine, J. N., Eddy, J. M., \& Sheeber, L., (2010). Maternal emotion coaching, adolescent anger regulation, and siblings' externalizing symptoms. Journal of Child Psychology and Psychiatry. 51(7), 799-808. doi:10.1111/j.1469-7610.2009.02207.x

Smetana, J. G., Campione-Barr, N., \& Metzger, A. (2006). Adolescent development in interpersonal and social contexts. Annual Review of Psychology, 57, 225-284. doi:10.1146/annurev.psych.57.102904.190124

Smetana, J. G. (2011). Adolescent's social reasoning and relationships with parents: Conflicts and coordination within and across domains. In E. Amsel \& J. Smetana (Eds.), Adolescent vulnerabilities and opportunities: Constructivist and developmental perspectives (pp. 139-158). New York: Cambridge University Press.

Somerville, L. H., Jones, R. M., \& Casey, B. J. (2010). A time of change: Behavioral and neural correlates of adolescent sensitivity to appetitive and aversive environmental cues. Brain and Cognition 72(1), 124-133. doi:10.1016/ j.bandc.2009.07.003

Steinberg, L., \& Silk, J. S. (2002). Parenting adolescent. In M. H. Bornstein (Ed.), Handbook of parenting: Volume 1. Children and Parenting (2nd ed., pp. 103-113). Mahwah, NJ: Eribaum.

Tao, A., Zhou, Q, \& Wang, Y. (2010). Parental reactions to children's negative emotions: Prospective relation to Chinese children's psychological adjustment. Journal of Family Psychology, 24(2). 135-144. doi:10.1037/a0018974

Yap, M. B. H., Schwartz, O. S., Byrne, M. L., Simmons, J. G., \& Allen, N. B. (2010). Maternal positive and negative interaction behaviors and early adolescents' depressive symptoms: Adolescent emotion regulation as a mediator. Journal of Research on Adolescence, 20(4). 1014-1043. doi:10.1111/j.1532-7795.2010.00665.x

Zeman, J., Klimes-Dougan, B., Cassano, M., \& Adrian, M. (2007). 
Measurement issues in emotion research with children and adolescents. Clinical Psychology: Science and Practice. 14(4), 377-401. doi:10.1111/j.1468-2850.2007.00098.x

Zeman, J., Shipman, K., \& Penza-Clyve, S. (2001). Development and initial validation of the children's sadness management scale. Journal of Nonverbal Behavior, 25(3), 187-205.

Zeman, J., Shipman. K., \& Suveg. C. (2002). Anger and sadness regulation: Predictions to internalizing and externalizing symptoms in children. Journal of Clinical Child and Adolescent Psychology, 31(3), 393-398.

\section{In Korean}

Bae, B. (2014). Structural equation modeling with AMOS 21. Seoul: Cheong-ram.

Christian Broadcasting System. (2016). Sesangeul bakkuneun sigan 15 bun[세상을 바꾸는 시간 15분]. Retrieved from CBS website: http://www.cbs.co.kr

Choi, H.-Y., Min, K.-W., \& Lee, D.-G. (2008). The role of ambivalence over emotional expression in the link of belief in emotional expression and psychological symptoms. The Korean Journal of Youth Counseling, 9(3), 1063-1080.

Hong, S. H. (2013). Various models of structural equation model (Unpublished Manuscript). Proceedings of S\&N Research Group, Research Methods Workshop.

Ihm, M.-O., Song, M.-K., \& Kim, C.-S. (2012). A mediating model of social support between anger and psychological maladaptation of adolescents. Korean Journal of Youth Studies, 19(4), 247-270.

Jeong, Y.-S. (2007). The difference of college students' anger expression by perceived parental acceptance-rejection rearing attitude. The Korean Journal of Youth Counseling, 15(1), 91-103.

Joo, J. Y. (2009). The study on the relationship among anger expression mode, depression and aggression in high school students. Journal of Student Guidance \& Counseling, 22, 7395.

Kim, E. J. (2001). Modes of anger expression of child and parents' child-rearing types and psychological growth environment (Master's thesis). Retrieved from http://www.riss.kr/ link?id=T8062970

Kim, E. J. (2011). Mother's acceptance attitude toward negative emotion and children's anger expression mode (Master's thesis). Retrieved from http://www.riss.kr/link?id=T12291736

Kim, N. H. (2017). The causal model analysis in the relationships among mother's reactions to early adolescent's anger, anger management styles and problem behaviors (Doctoral dissertation). Retrieved from http://www.riss.kr/ link?id=T14460758

Kim, H.-H. (2016). The moderator effect of appearance dissatisfaction the relationship between narcissism and depression of early adolescents. Journal of the Korea Institute of Youth Facility and Environment, 14(3), 113-123.

Kim, H. Y. (2015). Anger assessment using state-trait anger expression inventory in middle-school students in korea and association with depression (Master's thesis). Retrieved from http:// www.riss.kr/link?id=T13858968

Kim, M. H. (2011). The effects of adolescent's perceived parent-child attachment security and self-esteem on anger (Master's thesis). Retrieved from http://www.riss.kr/link?id=T12508101

Kim, N. H., \& Kim, H. H. (2017). The mediating effects of early adolescent's anger management styles in the relationships between mother's reactions to early adolescent's anger and externalizing problem behaviors. Korean Journal of Youth Studies, 24(9), 387-410.

Noh, J.-Y., \& Jeong, Y.-K. (2010). The effect of mother's reactions to child's negative emotion on ambivalence over emotional expressiveness and belief about emotional expression. The Korean Journal of Developmental Psychology, 23(2), 57-71.

Park, S.-A. (2010). The effect of college students' perceived parentadolescent communication style and parenting attitude on anger expression (Master's thesis). Retrieved from http:// www.riss.kr/link?id=T11960737

Park, J. K. (2001). The relations of the maternal monitoring and information sources of parental knowledge to externalizing and internalizing behaviors of adolescents (Master's thesis). Retrieved from http://www.riss.kr/link?id =T8952307

Park, K.-H. (2009). Parental reaction towards their children's negative emotion according to children's age and gender (Master's thesis). Retrieved from http://www.riss.kr/ link?id=T11732818

Shin, J. A. (2013). The relationships among parents' and teachers' empathy perceived by children, their anger expression pattern, and aggression (Master's thesis). Retrieved from http://www. riss.kr/link?id=T13173694

Yoon, J. I. (2013). Impact of anger representation and social support on psychological maladjustment in the youth (Master's thesis). Retrieved from http://www.riss.kr/link?id=T13428042

\section{ORCID}

$\mathrm{Na}$ Hyeon Kim http://orcid.org/0000-0001-7467-0822

Hee Hwa Kim http://orcid.org/0000-0003-0829-3226

Received December 10, 2017 Revision received February 5, 2018 Accepted February 14, 2018 